\title{
Adherence to Diaphragm Use for Infection Prevention: A Prospective Study of Female Sex Workers in Kenya
}

\author{
Elizabeth A. Bukusi, ${ }^{1,2,3,4}$ Maria F. Gallo, ${ }^{5}$ Anjali Sharma,, 4,6 Betty Njoroge, ${ }^{1,2}$ \\ Denise J. Jamieson, ${ }^{5}$ Rosemary Nguti, ${ }^{7}$ April J. Bell, ${ }^{5}$ and David A. Eschenbach ${ }^{4}$ \\ ${ }^{1}$ Center for Microbiology Research, Kenya Medical Research Institute, Mbagathi Rd., P.O. Box 54840-00200, Nairobi, Kenya \\ ${ }^{2}$ Department of Obstetrics and Gynecology, University of Nairobi, P.O. Box 30197, G.P.O, Nairobi, Kenya \\ ${ }^{3}$ Department of Global Health, University of Washington, 1959 N.E. Pacific St., Box 356355 Seattle, WA 98195-6355, USA \\ ${ }^{4}$ Department of Obstetrics and Gynecology, Department of Obstetrics \& Gynecology, University of Washington, \\ Box 356560, Seattle, WA 98195-6460, USA \\ ${ }^{5}$ Division of Reproductive Health, National Center for Chronic Disease Prevention and Health Promotion, Centers for \\ Disease Control and Prevention, 4770 Buford Highway, Mail Stop K-34, Atlanta, GA 30341-3724, USA \\ ${ }^{6}$ International Training and Education Center on HIV (I-TECH), University of Washington, 901 Boren Ave., Suite 1100, \\ Seattle, WA, 98104, UK \\ ${ }^{7}$ School of Mathematics, University of Nairobi, P.O. Box 30197, G.P.O, Nairobi, Kenya
}

Correspondence should be addressed to Maria F. Gallo, mgallo@cdc.gov

Received 26 August 2009; Revised 16 November 2009; Accepted 21 December 2009

Recommended by Susan Cu-Uvin

Objective. To assess adherence to and acceptability of the diaphragm among 140 female sex workers in Kenya in a 6-month prospective study. Methods. At baseline and bimonthly visits, participants were interviewed on diaphragm knowledge, attitude, and practices. We used principal component analysis and logistic regression to identify predictors of consistent use. Results. At $50 \%$ of 386 bimonthly visits, women reported consistently using a diaphragm with all partners during the preceding 2 weeks. Consistent use was significantly higher at the 6-month than the 2-month visit. Women reported less covert use with "helping" (regular sex partners to whom she could go for help or support) than with "other" partners. Perceptions that diaphragms are easier to use than condoms and that their lack of coital interruption is important were associated with consistent diaphragm use with both partner types. Partner support of diaphragm use is correlated with consistent use with "helping" partners only while higher parity, consistent condom use, and perceived lack of need of condoms as a benefit of diaphragms were associated with consistent use with "other" partners. Conclusions. Diaphragm acceptance among female sex workers in Nairobi was high. Future studies should distinguish between partner types when evaluating diaphragm adherence.

Copyright (C) 2009 Elizabeth A. Bukusi et al. This is an open access article distributed under the Creative Commons Attribution License, which permits unrestricted use, distribution, and reproduction in any medium, provided the original work is properly cited.

\section{Introduction}

Cervical barriers such as diaphragms may protect women against the acquisition of sexually transmitted infections (STIs). Diaphragms could prevent N. gonorrhoeae and C. trachomatis from reaching the target columnar epithelial cells in the cervix [1] and protect against HIV acquisition by reducing the risk of the virus reaching HIV receptor-rich cells, which are present in larger numbers in the cervix than in the vagina [2-6]. In addition, diaphragms may reduce HIV susceptibility indirectly by protecting against other STIs [7,
8] and could be an effective mechanism with which to deliver microbicide in the genital tract if a microbicide effective against HIV were identified [9]. Although diaphragms have not been shown to be effective against HIV acquisition in a randomized controlled trial [10], observational data suggest that consistent diaphragm use could protect against STIs and their long-term sequelae [11].

Even if diaphragms were proven to be efficacious for STI prevention and safe for use in diverse populations, they would still have to be acceptable to potential users in order to be used consistently. Although diaphragm 
use has been shown to have a high rate of acceptability among women, many factors could influence adherence to diaphragm usage instructions, including the attributes of specific types of diaphragms (e.g., their reusability), how they are used (e.g., when they need to be inserted and removed, whether they are used with a microbicide gel, and whether users are instructed to refrain from concomitant douching or intravaginal cleansing), and partner knowledge of their use [12-21]. Although diaphragms are "female-controlled" devices, partners' attitudes toward their use could affect women's adherence to consistent usage. Covert diaphragm use, especially with regular partners, can be difficult to maintain long-term, and unintended discovery of diaphragm use could cause conflict between women and partners who object to the use of diaphragms $[22,23]$. We conducted a 6-month prospective study to measure the prevalence of consistent diaphragm use and to identify determinants of consistent use among female sex workers in Kibera in Nairobi, Kenya.

\section{Materials and Methods}

2.1. Study Procedures. The study was conducted from 2004 to 2005 among female sex workers (i.e., women who reported trading sex for money or gifts in the prior 2 weeks), 18-57 years of age, in the Kibera settlement in Nairobi, Kenya who had previously participated in a randomized trial of monthly chemical prophylaxis for STI control and prevention [24]. Findings on the safety of diaphragm use and changes in condom use in this population will be reported separately. Women were ineligible for the study if they reported consistent condom use during the previous 2 months or if they had a current pregnancy, gynecological abnormalities precluding diaphragm use, latex allergies, a partner with latex allergies, or a history of toxic shock syndrome.

At baseline, participants underwent a pelvic examination and were fitted for the silicone Milex Wide Seal diaphragm (Milex Inc., Chicago, IL). After being counseled on diaphragm use, women practiced inserting and removing their diaphragm under a clinician's observation. They were instructed to apply 1-2 teaspoons of K-Y Jelly (Johnson and Johnson; New Brunswick, New Jersey) to the cup and rim of the diaphragm for lubrication before inserting it and to keep the diaphragm in their vagina for at least 6 hours after coitus (without internal vaginal cleansing) but not for more than 24 hours. Women were given two diaphragms, a supply of K-Y Jelly, and male condoms.

At follow-up visits scheduled 1 week and 2, 4, 6 months after the baseline visit, women were counseled on safer sex practices and instructed to have their partners use a male condom during every coital act. They were counseled on the limited contraceptive effectiveness of diaphragms when used without spermicide and the unknown effectiveness of the diaphragm against STI acquisition. At all visits, they were tested for pregnancy and urinary tract infection and were treated syndromically for STIs and reproductive tract infections. The pelvic examination was repeated at the 6month visit.
Women were interviewed at the baseline visit and at the 2-, 4-, and 6-month follow-up visits to collect demographic data and data on their sexual behaviors; adherence to diaphragm use; and knowledge, attitude, and practices regarding diaphragms (as well as their perceptions of their partners' attitudes about diaphragm use). The questionnaires distinguished between diaphragm use with a "helping" partner and with all "other" partners. These partner types were established based on earlier formative research with the target population. A "helping" partner was defined as a regular sex partner to whom a woman could go for help or support if needed. If women had multiple partners in the past two weeks, they were asked to consider their main "helping" partner and their most recent "other" partner while answering the questionnaires. At all follow-up visits, participants completed a self-administered questionnaire about the frequency of their diaphragm, gel, and condom use for all acts with partners in the previous 2 weeks.

2.2. Statistical Analysis. SAS 9.1.3 (SAS Institute, Cary, NC) was used for data analysis. Consistent use was defined with a categorical variable that measured diaphragm use (with or without K-Y Jelly) for all coital acts in the previous 2 weeks and analyzed separately for "helping" and "other" partners. The analyses were restricted to follow-up visits in which women reported at least one coital act in the preceding 2week period with the relevant partner type. The adjusted Wald method ${ }^{24}$ was used to calculate $95 \%$ confidence intervals for estimates of the percentage of women who used a diaphragm consistently, and chi-squared tests were used to assess differences between the percentages of women who reported consistent diaphragm use and covert diaphragm use at their 2-month visit and the percentages who did so at their 6-month visit.

In separate principal component analyses, we assessed the extent to which 25 and 26 factors were related to diaphragm use with "helping" partners and "other" partners, respectively. The association of each factor with diaphragm use was based on participants' responses to statements about the diaphragm, which originally were measured with a three-item Likert scale; however, we recoded the responses for our analysis as "agree" versus "neutral or disagree." Principal component analysis is a method used to collapse a large number of partially correlated variables into fewer uncorrelated factors, each representing the combination of two or more of the initial variables [25]. This decreases the risk for type I errors (by reducing the number of statistical tests performed) as well as the risk for type II errors. Use of such a summary risk factor instead of multiple correlated items tends to produce stronger and more precise measures of association when a true association with the outcome of interest exists [26].

The derived variables then can be used in other analyses; for example, they can be regressed against the outcome of interest. We used the principal axis method to extract the components and the varimax method to produce orthogonal (uncorrelated) components. We based the decision to retain components on eigenvalues greater than 1 and the location 
TABle 1: Baseline sociodemographic and selected characteristics among study participants who completed at least one follow-up visit $(N=138)$, Nairobi, Kenya, 2004-2005.

\begin{tabular}{|c|c|c|}
\hline Characteristics & No. & $(\%)$ \\
\hline \multicolumn{3}{|l|}{ Age } \\
\hline$\leq 27$ years & 47 & $(34)$ \\
\hline $28-34$ years & 46 & $(33)$ \\
\hline$\geq 35$ years & 45 & $(33)$ \\
\hline \multicolumn{3}{|l|}{ Marital status } \\
\hline Never married and not cohabiting & 37 & $(27)$ \\
\hline Cohabiting, divorced or widowed & 101 & $(73)$ \\
\hline \multicolumn{3}{|l|}{ Ethnicity } \\
\hline Kikuyu & 68 & $(49)$ \\
\hline Other & 70 & $(51)$ \\
\hline \multicolumn{3}{|l|}{ Education completed } \\
\hline $0-8$ years & 112 & $(81)$ \\
\hline $9-12$ years & 26 & $(19)$ \\
\hline \multicolumn{3}{|l|}{ Income per week } \\
\hline$\leq 9$ US dollars & 70 & $(51)$ \\
\hline$>9$ US dollars & 68 & $(49)$ \\
\hline \multicolumn{3}{|l|}{ Current primary birth control method } \\
\hline None & 19 & $(14)$ \\
\hline Condoms & 49 & $(40)$ \\
\hline Hormonal contraception & 47 & $(38)$ \\
\hline \multirow[t]{2}{*}{ IUD or tubal ligation } & 8 & $(7)$ \\
\hline & Median & (Range) \\
\hline Number of children & 3 & $(0-10)$ \\
\hline Age at first intercourse & 16 & $(10-25)$ \\
\hline Vaginal cleansing in past week & 11 & $(1-30)$ \\
\hline Sexual partners in past two weeks & 5 & $(1-56)$ \\
\hline
\end{tabular}

of the break on the scree test. Factors that load for a given analysis are those that were given substantial weight when the principal component was constructed. We considered a factor to load for a component if the factor loading was at least .40 for the given component and less than .40 for the other components in the rotated factor pattern. The SAS procedure used for this analysis automatically standardized the component scores to unit variance. We retained two components in our subsequent analysis of factors related to diaphragm use with "helping" partners and with "other" partners. Tables 2 and 4 show the factors that loaded on each of the components. The communality estimate expresses the percentage of variance in the original variables that is accounted for by the retained principal components.

To identify determinants of consistent diaphragm use, we used logistic regression with generalized estimating equations, with the exchangeable working correlation matrix specified to adjust for correlation of standard errors between multiple records from one participant. After fitting individual models to perform bivariable analyses, we then fit a full model with all variables for the multivariable analysis. Using manual backward elimination, we removed factors that did not predict consistent diaphragm use based on an alpha of 0.05. Time-independent factors that were assessed as predictors of consistent diaphragm use were measured at baseline; these factors included age ( $\leq 27,28-34, \geq 35$ years), marital status (never married and not cohabiting versus cohabiting, divorced, or widowed), highest educational level completed ( $<8$ versus 9-12 years), ethnicity (Kikuyu versus other), weekly income ( $\leq 9$ versus $>9$ USD), parity (0-1 versus $\geq 2$ children), perceived importance of preventing pregnancy (not at all versus moderately or a lot), worry about pregnancy (not at all versus moderately or a lot), and worry about HIV (not at all versus moderately or a lot). Timedependent factors describing behaviors in the preceding 2 weeks were measured at the bimonthly visits, these included number of sex partners ( $1-5$ versus $\geq 6$ ), number of new sex partners $(0,1-2, \geq 3)$, coital frequency with all partners $(0-5$, $6-15, \geq 16$ acts), any condom use with "helping" or "other" partners (yes versus no), a variable for the bimonthly $(2,4$, or 6-month) visit, the components constructed in the principal component analysis; and the variables that did not load on the components created in the principal component analysis.

Only women who gave written, informed consent participated. Ethical review committees at the University of Nairobi, the University of Washington, the University of California, San Francisco, and the US Centers for Disease Control and Prevention approved the research.

\section{Results}

3.1. Study Population. Of the 180 women who were screened, 140 met the eligibility criteria and were enrolled in the study. Most women completed the 2-month $(n=134)$, 4-month $(n=130)$, and 6-month visits $(n=126)$. Overall, 138 (99\%) of women enrolled in the study completed at least one of the bimonthly visits, and 121 (86\%) completed all three bimonthly visits. Study attrition was due to pregnancy $(n=8)$, moving $(n=3)$, and loss to follow-up $(n=3)$. Analyses of diaphragm use with "helping" partners were based on data collected during 313 bimonthly visits by 121 women who reported coitus with a "helping" partner during at least one bimonthly visit. Analyses of diaphragm use with "other" partners were based on data collected during 362 bimonthly visits by 135 women who reported at least one act with any "other" type of partner during at least one bimonthly visit. Analyses of diaphragm use with all partners were based on data collected during 386 bimonthly visits by 138 women who reported at least one act with either partner type during at least one bimonthly visit. Participants' median age was 30 years (range, 18-55); $73 \%$ were cohabiting, divorced, or widowed; $81 \%$ had less than 8 years of education (Table 1). Most participants (63\%) reported having previously used condoms for contraception. Only one woman reported having ever used a diaphragm before.

3.2. Adherence and Covert Use. Women reported that they used a diaphragm with all partners during the preceding 2 weeks at $50 \%$ of the bimonthly visits, with all "helping" partners at $59 \%$ of the visits, and with all "other" partners 
TABLE 2: Rotated factor pattern and final communality estimates from principal component analysis of participants' (and participants' perception of partners') knowledge, attitude, or practices regarding diaphragm use with "helping" partner, Nairobi, Kenya, 2004-2005* .

\begin{tabular}{|c|c|c|c|}
\hline Knowledge, attitude, or practices ${ }^{\dagger}$ & $\begin{array}{l}\text { Component } 1 \text { (Perceived } \\
\text { partner support of } \\
\text { diaphragm use) }\end{array}$ & $\begin{array}{l}\text { Component } 2 \text { (Attitudes } \\
\text { toward study product } \\
\text { attributes)* }\end{array}$ & Communality estimate \\
\hline $\begin{array}{l}\text { Unlikely that "helping" partner would make } \\
\text { fun of participant for diaphragm }+ \text { gel use }\end{array}$ & $.58^{*}$ & .01 & .33 \\
\hline $\begin{array}{l}\text { Unlikely that "helping" partner would argue } \\
\text { because of diaphragm }+ \text { gel use }\end{array}$ & $.89^{*}$ & .12 & .80 \\
\hline $\begin{array}{l}\text { Unlikely that "helping" partner would get } \\
\text { mad because of diaphragm }+ \text { gel use }\end{array}$ & $.87^{*}$ & .14 & .77 \\
\hline $\begin{array}{l}\text { Unlikely that "helping" partner would hit or } \\
\text { beat participant because of diaphragm }+ \text { gel } \\
\text { use }\end{array}$ & $.76^{*}$ & .05 & .57 \\
\hline $\begin{array}{l}\text { Unlikely that "helping" partner would refuse } \\
\text { sex because of diaphragm + gel use }\end{array}$ & $.91^{*}$ & .13 & .84 \\
\hline $\begin{array}{l}\text { Unlikely that "helping" partner would end } \\
\text { relationship because of diaphragm + gel use }\end{array}$ & $.89^{*}$ & .12 & .81 \\
\hline $\begin{array}{l}\text { Unlikely that "helping" partner would stop } \\
\text { support because of diaphragm + gel use }\end{array}$ & $.89^{*}$ & .08 & .80 \\
\hline $\begin{array}{l}\text { If participant wanted to use } \\
\text { diaphragm + gel and "helping" partner did } \\
\text { not, he would not refuse to have sex with } \\
\text { diaphragm + gel }\end{array}$ & $.69^{*}$ & .06 & .48 \\
\hline $\begin{array}{l}\text { If participant wanted to use } \\
\text { diaphragm + gel and "helping" partner did } \\
\text { not, he would not talk participant out of use }\end{array}$ & $.51^{*}$ & .14 & .28 \\
\hline $\begin{array}{l}\text { If participant wanted to use } \\
\text { diaphragm + gel and "helping" partner did } \\
\text { not, he would not insist on non-use }\end{array}$ & $.51^{*}$ & .13 & .28 \\
\hline $\begin{array}{l}\text { "Helping partner" likes extra lubrication } \\
\text { from diaphragm + gel use }\end{array}$ & $.46^{*}$ & .31 & .30 \\
\hline $\begin{array}{l}\text { Likes extra lubricant from diaphragm + gel } \\
\text { use }\end{array}$ & .10 & $.63^{*}$ & .41 \\
\hline $\begin{array}{l}\text { No hormonal side effects is benefit of } \\
\text { diaphragm }+ \text { gel use }\end{array}$ & .01 & $.51^{*}$ & .26 \\
\hline $\begin{array}{l}\text { Lubrication is benefit of diaphragm }+ \text { gel } \\
\text { use }\end{array}$ & .09 & $.63^{*}$ & .40 \\
\hline $\begin{array}{l}\text { Uninterrupted sex is benefit of } \\
\text { diaphragm }+ \text { gel use }\end{array}$ & .10 & $.62^{*}$ & .39 \\
\hline
\end{tabular}

*Factor loading was 40 or greater for the given component; based on 313 intervals from 121 women who reported having sex with "helping" partner during at least one follow-up interval.

†The following factors did not load on either component: Diaphragm + gel use is easier than condom use; Diaphragms + gel are very effective in protecting against HIV or other STDs; Diaphragms + gel are very effective in protecting against pregnancy; Important to use diaphragms + gel with all partners; Does not prefer condoms to diaphragm + gel; Plans to use diaphragm + gel at next coitus with "helping" partner; Ability to use without partner permission is benefit of diaphragm + gel use; Ability to use without partner awareness is benefit of diaphragm + gel use; No need for condoms is benefit of diaphragm + gel; Important that diaphragm use does not interrupt sex.

at $64 \%$ of the visits. Among the subset reporting at least one act with the relevant partner type during the bimonthly visits, $41 \%, 45 \%$, and $33 \%$ of women reported consistent diaphragm use with "helping," "other," or all partners, respectively.

The percentage of women who reported consistent diaphragm use increased over the course of the study (Figure 1). The proportion of women who reported consistent diaphragm use was significantly higher at the 6-month visit than the 2-month visit for coital acts with "helping" partners $(P=.04)$ and with "other" partners $(P=.04)$ but not for coital acts with all partners $(P=.09)$.

Results of analyses limited to visits by women who reported at least some diaphragm use with the relevant partner type showed that women reported always using the diaphragm without their "helping" partners' knowledge at $55 \%$ of the bimonthly visits and without their "other" partners' knowledge at $76 \%$ of the visits. The percentage of women who reported consistent covert use of the diaphragm during the preceding 2 weeks did not vary significantly 
TABle 3: Associations between consistent diaphragm use with "helping" partner during previous 2 weeks and selected demographic characteristics and attitudes toward diaphragm use, Nairobi, Kenya, 2004-2005*.

\begin{tabular}{|c|c|c|c|c|c|c|}
\hline & \multirow{2}{*}{$\begin{array}{l}\text { No. of intervals with } \\
\text { consistent use }\end{array}$} & \multirow{2}{*}{$\begin{array}{l}\text { No. of intervals without } \\
\text { consistent use }\end{array}$} & \multicolumn{2}{|c|}{ Bivariable model } & \multicolumn{2}{|c|}{ Multivariable model $^{\dagger}$} \\
\hline & & & OR & $(95 \% \mathrm{CI})$ & OR & $(95 \% \mathrm{CI})$ \\
\hline \multicolumn{7}{|l|}{ Time-independent factors } \\
\hline \multicolumn{7}{|l|}{ Age } \\
\hline$\leq 27$ years & 63 & 49 & \multicolumn{2}{|c|}{ Referent } & & \\
\hline $28-34$ years & 75 & 45 & 1.4 & $(0.7,2.7)$ & & \\
\hline$\geq 35$ years & 46 & 35 & 1.1 & $(0.5,2.4)$ & & \\
\hline \multicolumn{7}{|l|}{ Marital status } \\
\hline Never married and cohabiting & 57 & 34 & 1.2 & $(0.6,2.2)$ & & \\
\hline Cohabiting, divorced or widowed & 127 & 95 & \multicolumn{2}{|c|}{ Referent } & & \\
\hline \multicolumn{7}{|l|}{ Education completed } \\
\hline $0-8$ years & 141 & 104 & \multicolumn{2}{|c|}{ Referent } & & \\
\hline $9-12$ years & 43 & 25 & 1.3 & $(0.6,2.8)$ & & \\
\hline \multicolumn{7}{|l|}{ Parity } \\
\hline 0-1 children & 45 & 35 & \multicolumn{2}{|c|}{ Referent } & & \\
\hline$\geq 2$ children & 139 & 94 & 1.2 & $(0.6,2.3)$ & & \\
\hline \multicolumn{7}{|l|}{ Time-dependent factors } \\
\hline \multicolumn{7}{|l|}{ Study follow-up visit } \\
\hline 2-month & 55 & 53 & \multicolumn{2}{|c|}{ Referent } & & \\
\hline 4-month & 63 & 40 & 1.4 & $(0.9,2.2)$ & & \\
\hline 6-month & 66 & 36 & 1.5 & $(1.0,2.4)$ & & \\
\hline \multicolumn{7}{|l|}{ All sex partners in past 2 weeks } \\
\hline $1-5$ & 106 & 61 & 1.2 & $(0.8,1.9)$ & & \\
\hline $6-42$ & 78 & 68 & \multicolumn{2}{|c|}{ Reference } & & \\
\hline \multicolumn{7}{|l|}{$\begin{array}{l}\text { Coital acts with all partners in past } 2 \\
\text { weeks }\end{array}$} \\
\hline $0-5$ acts & 31 & 17 & 1.5 & $(0.7,2.8)$ & & \\
\hline $6-15$ acts & 109 & 73 & 1.3 & $(0.8,2.2)$ & & \\
\hline$\geq 16$ acts & 44 & 39 & & eferent & & \\
\hline \multicolumn{7}{|l|}{$\begin{array}{l}\text { Consistent condom use with "helping" } \\
\text { partner in past } 2 \text { weeks }\end{array}$} \\
\hline Yes & 57 & 26 & 1.5 & $(0.9,2.6)$ & & \\
\hline No & 127 & 103 & \multicolumn{2}{|c|}{ Referent } & & \\
\hline $\begin{array}{l}\text { Component } 1 \text { (Perceived partner } \\
\text { support of diaphragm use) }\end{array}$ & & & 1.3 & $(1.1,1.7)$ & 1.4 & $(1.1,1.7)$ \\
\hline $\begin{array}{l}\text { Component } 2 \text { (Attitudes toward study } \\
\text { product attributes) }\end{array}$ & & & 1.2 & $(1.0,1.5)$ & & \\
\hline \multicolumn{7}{|l|}{$\begin{array}{l}\text { Diaphragm }+ \text { gel use is easier than } \\
\text { condom use }\end{array}$} \\
\hline Yes & 140 & 81 & 1.9 & $(1.2,3.1)$ & 2.0 & $(1.2,3.1)$ \\
\hline No & 44 & 48 & & & & \\
\hline \multicolumn{7}{|l|}{$\begin{array}{l}\text { Important to participant that } \\
\text { diaphragm use does not interrupt sex }\end{array}$} \\
\hline Yes & 176 & 119 & 2.7 & $(1.1,6.6)$ & 2.8 & $(1.1,7.1)$ \\
\hline No & 8 & 10 & \multicolumn{2}{|c|}{ Referent } & & \\
\hline \multicolumn{7}{|c|}{$\begin{array}{l}\text { OR = odds ratio; CI = confidence interval } \\
\text { *Analyzed with logistic regression model with generalized estimating equations based on } 313 \text { intervals from } 121 \text { women who reported having sex with "helping" } \\
\text { partner during at least one follow-up interval. } \\
{ }^{\dagger} \text { Adjusted for all variables in column. } \\
\text { The following variables also were analyzed but were not associated with consistent diaphragm use: ethnicity (Kikuyu versus other), education ( } \leq 9 \text { USD versus >9 } \\
\text { USD); important to prevent pregnancy (not at all versus moderately or a lot); worry about pregnancy (not at all versus moderately or a lot); worry about HIV (not } \\
\text { at all versus moderately or a lot); new main sex partners in past } 2 \text { weeks ( } 0 \text { versus } 1-2 \text { versus } \geq 3 \text { ); under the influence of alcohol during sex with "helping" partner } \\
\text { in past } 2 \text { weeks (never versus } \geq 1 \text { time); under the influence of "bhang" or other drugs during sex with "helping" partner in past } 2 \text { weeks (never versus } \geq 1 \text { time); and } \\
\text { the remaining factors that did not load in principal component analysis (listed in the footnote for Table } 2 \text { ). }\end{array}$} \\
\hline
\end{tabular}


TABLE 4: Rotated factor pattern and final communality estimates from principal component analysis of participants' (and perception of partners') knowledge, attitude, or practices regarding diaphragm use with “other” partners, Nairobi, Kenya, 2004-2005*.

\begin{tabular}{|c|c|c|c|}
\hline Knowledge, attitude, or practices ${ }^{\dagger}$ & $\begin{array}{l}\text { Component } 1 \text { (Perceived } \\
\text { partner support of } \\
\text { diaphragm use)* }\end{array}$ & $\begin{array}{c}\text { Component } 2 \text { (Attitudes } \\
\text { toward study product } \\
\text { attributes)* }\end{array}$ & Communality estimate \\
\hline $\begin{array}{l}\text { Unlikely that "other" partners would make } \\
\text { fun of participant for diaphragm }+ \text { gel use }\end{array}$ & $.64^{*}$ & .39 & .57 \\
\hline $\begin{array}{l}\text { Unlikely that "other" partners would get } \\
\text { angry because of diaphragm }+ \text { gel use }\end{array}$ & $.86^{*}$ & .31 & .83 \\
\hline $\begin{array}{l}\text { Unlikely that "other" partners would argue } \\
\text { because of diaphragm + gel use }\end{array}$ & $.86^{*}$ & .27 & .81 \\
\hline $\begin{array}{l}\text { Unlikely that "other" partners would get } \\
\text { mad because of diaphragm + gel use }\end{array}$ & $.89^{*}$ & .28 & .86 \\
\hline $\begin{array}{l}\text { Unlikely that "other" partners would hit or } \\
\text { beat her because of diaphragm }+ \text { gel use }\end{array}$ & $.72 *$ & .31 & .62 \\
\hline $\begin{array}{l}\text { Unlikely that "other" partners would refuse } \\
\text { sex because of diaphragm + gel use }\end{array}$ & $.83^{*}$ & .28 & .76 \\
\hline $\begin{array}{l}\text { If participant wanted to use } \\
\text { diaphragm + gel and "other" partners did } \\
\text { not, he would not refuse to have sex with } \\
\text { diaphragm + gel }\end{array}$ & $.67^{*}$ & .19 & .48 \\
\hline $\begin{array}{l}\text { If participant wanted to use } \\
\text { diaphragm + gel and "other" partners did } \\
\text { not, he would not talk participant out of use }\end{array}$ & $.52 *$ & .27 & .34 \\
\hline $\begin{array}{l}\text { If participant wanted to use } \\
\text { diaphragm + gel and "other" partners did } \\
\text { not, he would not refuse to pay }\end{array}$ & $.61^{*}$ & .21 & .41 \\
\hline $\begin{array}{l}\text { If participant wanted to use } \\
\text { diaphragm + gel and "other" partners did } \\
\text { not, he would still have sex with you }\end{array}$ & $.66^{*}$ & .26 & .49 \\
\hline $\begin{array}{l}\text { If participant wanted to use } \\
\text { diaphragm + gel and "other" partner did } \\
\text { not, he would not insist on nonuse }\end{array}$ & $.58^{*}$ & .30 & .42 \\
\hline $\begin{array}{l}\text { Likes extra lubrication from } \\
\text { diaphragm }+ \text { gel use }\end{array}$ & .09 & $.55^{*}$ & .31 \\
\hline $\begin{array}{l}\text { No hormonal side effects is benefit of } \\
\text { diaphragm }+ \text { gel use }\end{array}$ & .10 & $.50^{*}$ & .26 \\
\hline $\begin{array}{l}\text { Lubrication is benefit of diaphragm }+ \text { gel } \\
\text { use }\end{array}$ & .07 & $.56^{*}$ & .32 \\
\hline $\begin{array}{l}\text { Uninterrupted sex is benefit of } \\
\text { diaphragm }+ \text { gel use }\end{array}$ & .10 & $.61^{*}$ & .39 \\
\hline
\end{tabular}

*Factor loading was .40 or greater for the given component; based on 362 bimonthly study visits from 135 women who reported having sex with "other" partner during at least one bimonthly visit.

†The following factors did not load on either component: "Other" partner likes extra lubrication from diaphragm + gel use; Diaphragm + gel use is easier than condom use; Diaphragms + gel are very effective in protecting against HIV or other STDs; Diaphragms + gel are very effective in protecting against pregnancy; Important to use diaphragms + gel with all partners; Does not prefer condoms to diaphragm + gel; Plans to use diaphragm + gel at next coitus with "other" partner; Ability to use without partner permission is benefit of diaphragm + gel use; Ability to use without partner awareness is benefit of diaphragm + gel use; No need for condoms is benefit of diaphragm + gel; Important that diaphragm use does not interrupt sex.

between the 2- and 6-month visits either with "helping" partners (58\% and 51\%, resp.; $P=.56)$ or with "other" partners $(77 \%$ and $73 \%$, resp.; $P=.82)$.

3.3. Diaphragm Use with "Helping" Partners. Principal component analysis yielded two components associated with the use of a diaphragm with a "helping" partner (Table 2). The first component was participants' perception of the degree to which their "helping" partner would support their diaphragm use. Among the factors that loaded on this component was a woman's agreement that diaphragm use would be unlikely to cause her "helping" partner to refuse sex, argue about sex, end their relationship, stop supporting her, or become mad at her. The second component was a composite of woman's attitudes toward four attributes of diaphragms: liking the extra lubrication and viewing lack of hormonal side effects, lubrication, and ability to have uninterrupted sex as benefits of product use. 


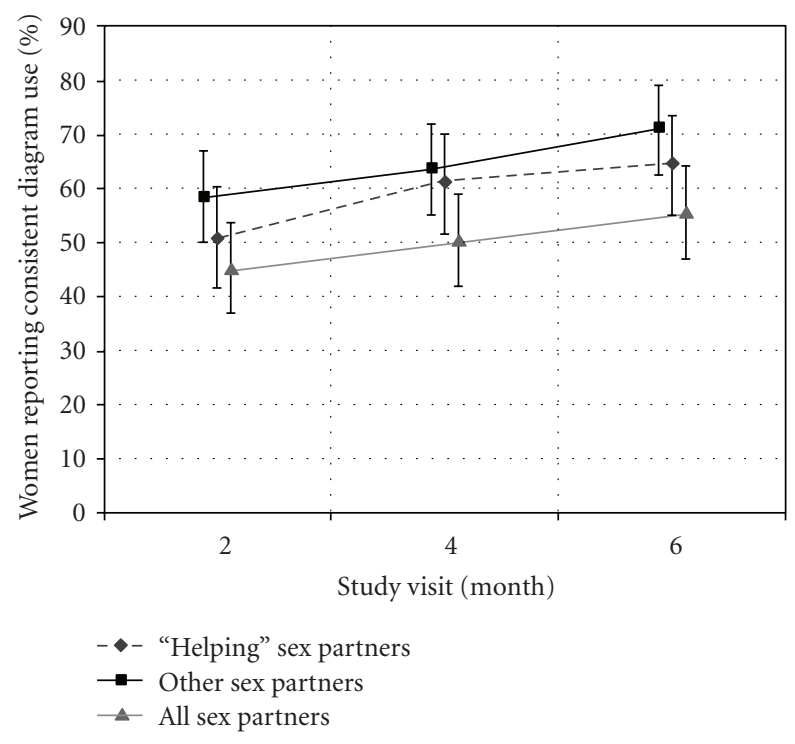

Figure 1: Prevalence of consistent diaphragm use, by partner type and study visit, Diaphragm Acceptability Study, Nairobi, Kenya, 2004-2005. Consistent use defined as diaphragm use during $100 \%$ of coital acts in the previous 2 weeks. Analysis restricted to women with at least one coital act in the previous 2 weeks with the relevant partner type. Bars represent 95\% confidence intervals.

Results from the unadjusted analysis showed that five variables were associated with reporting consistent diaphragm use with a "helping" partner in the prior 2 weeks: the time of the follow-up visit (6-month versus 2month visit), perceived partner support of diaphragm use, attitudes toward diaphragm attributes, the perception that using a diaphragm with gel use is at least as easy as using a condom, and the perceived importance of diaphragm use not interrupting sex (Table 3 ). In the multivariable analysis, however, the associations remained significant for only three variables: perceived partner support of diaphragm use (adjusted odds ratio [OR], 1.4; 95\% confidence interval [CI], 1.1-1.7), the perception that using a diaphragm with gel use is at least as easy as using a condom (adjusted OR, 2.0; 95\% CI, 1.2-3.1), and the perceived importance of diaphragm use not interrupting sex (adjusted OR, 2.8; 95\% CI, 1.1-7.1).

3.4. Diaphragm Use with "Other" Partners. Results from the principal component analysis showed two components significantly associated with diaphragm use with "other" partners (Table 4). The first was a composite of factors concerning women's perceptions of whether their "other" partners supported their diaphragm use, including whether diaphragm use would cause their "other" partners to become mad, angry, argue with her, refuse to have sex, or hit or beat her. The second component was based on the same four factors as the second component in the analysis of diaphragm use with "helping" partners.

Nine variables were related to consistent diaphragm use with "other" partners in the previous 2 weeks (Table 5). Four of these variables, however, were not associated with consistent diaphragm use in the adjusted model: study follow-up visit (6-month versus 2-month), number of recent sex partners, number of coital acts with all partners in the previous 2 weeks, and the second component. Only the following five variables were associated with consistent diaphragm use with "other" partners in the multivariable model: having $\geq 2$ children (adjusted OR, 2.1; 95\% CI, 1.14.0), using condoms consistently (adjusted OR, 2.1; 95\% CI, 1.2-3.7), perceiving diaphragm use to be easier than condom use (adjusted OR, 2.3; 95\% CI, 1.4-3.8), perceiving diaphragm use not interrupting sex as being important (adjusted OR, 2.2; 95\% CI, 1.0-5.0), and perceiving the lack of need for condoms as a benefit of diaphragm + gel use (adjusted OR, 2.3; 95\% CI, 1.3-4.2).

3.5. Reasons for Not Using a Diaphragm. The most common explanation that women gave for not using a diaphragm was that they used condoms instead; $75 \%$ of the women who reported inconsistent diaphragm use during the previous 2 weeks cited this reason one or more times (Table 6). This explanation was provided more often to explain not using a diaphragm with "other" partners $(82 \%)$ than with "helping" partners (38\%). Women often cited "trust" and "knowing partners well enough not to use it" as reasons for not using diaphragms with "helping" partners but rarely given cited either as a reason for not using a diaphragm with "other" partners. Another frequently cited reason for not using a diaphragm was that sex was unexpected or that women did not have the diaphragm with them (cited by $30 \%$ as a reason with "helping" partners and by 53\% as reasons with "other" partners). In contrast, negative attributes of the diaphragm (e.g., participant discomfort) were rarely reported as reasons for not using it.

\section{Discussion}

A substantial proportion of participants reported consistent diaphragm use in the prior 2 weeks with "helping" and "other" partners (59\% and 64\% of follow-up visits, resp.). Diaphragm use with each partner type increased over the course of the study. With one exception [12], results from studies of diaphragm use for infection control have shown little change over time in the percentage of women who reported consistent use during study visits [15, 17, 19, 21]. The increase that we found in the percentage of women who used diaphragms consistently might be the product of a "learning curve," whereby women learned to use the device more consistently or became more comfortable with its use over time. Because of the low attrition rate in the study, the increase in the rate of consistent diaphragm use is unlikely to be attributable completely to early study discontinuation by women who did not like the diaphragm.

The perceptions that diaphragms are easier to use than condoms and that lack of interruption to sex is important were associated with consistent diaphragm use with both partner types. The association of other factors with consistent diaphragm use, however, differed by partner type. Women's perception of the degree to which their "helping" 
TABle 5: Associations between consistent diaphragm use with "other" partners in previous 2 weeks and selected demographic characteristics and attitudes toward diaphragm use, Nairobi, Kenya, 2004-2005*.

\begin{tabular}{|c|c|c|c|c|c|c|}
\hline & $\begin{array}{l}\text { No. of intervals } \\
\text { with consistent } \\
\text { use }\end{array}$ & $\begin{array}{l}\text { No. of intervals } \\
\text { without } \\
\text { consistent use }\end{array}$ & $\begin{array}{l}\text { OR } \\
\text { Bivar }\end{array}$ & $\begin{array}{l}(95 \% \mathrm{CI}) \\
\text { riable model }\end{array}$ & $\begin{array}{c}\text { OR } \\
\text { Multivaria }\end{array}$ & $\begin{array}{l}(95 \% \mathrm{CI}) \\
\text { able model }^{\dagger} \\
\end{array}$ \\
\hline \multicolumn{7}{|l|}{ Time-independent factors } \\
\hline \multicolumn{7}{|l|}{ Age } \\
\hline$\leq 27$ years & 73 & 53 & \multicolumn{2}{|r|}{ Referent } & & \\
\hline 28-34 years & 81 & 40 & 1.5 & $(0.8,3.0)$ & & \\
\hline$\geq 35$ years & 79 & 36 & 1.6 & $(0.8,3.3)$ & & \\
\hline \multicolumn{7}{|l|}{ Marital status } \\
\hline Never married and cohabiting & 64 & 36 & \multicolumn{2}{|r|}{ Referent } & & \\
\hline Cohabiting, divorced or widowed & 169 & 93 & 1.1 & $(0.6,2.0)$ & & \\
\hline \multicolumn{7}{|l|}{ Education completed } \\
\hline $0-8$ years & 193 & 105 & \multirow{2}{*}{\multicolumn{2}{|c|}{$\begin{array}{c}(0.5,2.2) \\
\text { Referent }\end{array}$}} & & \\
\hline $9-12$ years & 40 & 24 & & & & \\
\hline \multicolumn{7}{|l|}{ Parity } \\
\hline $0-1$ children & 45 & 43 & \multicolumn{2}{|r|}{ Referent } & \multicolumn{2}{|c|}{ Referent } \\
\hline$\geq 2$ children & 188 & 86 & 2.2 & $(1.2,4.0)$ & 2.1 & $(1.1,4.0)$ \\
\hline \multicolumn{7}{|l|}{ Time-dependent factors } \\
\hline \multicolumn{7}{|l|}{ Study follow-up visit } \\
\hline 2-month & 75 & 53 & & Referent & & \\
\hline 4-month & 78 & 44 & 1.2 & $(0.8,1.8)$ & & \\
\hline 6-month & 80 & 32 & 1.7 & $(1.1,2.6)$ & & \\
\hline \multicolumn{7}{|l|}{ All sex partners in past 2 weeks } \\
\hline $1-5$ & 116 & 54 & 1.5 & $(1.0,2.1)$ & & \\
\hline $6-42$ & 117 & 75 & & Referent & & \\
\hline \multicolumn{7}{|l|}{ Coital acts with all partners in past 2 weeks } \\
\hline $0-5$ acts & 41 & 14 & 2.1 & $(1.0,4.3)$ & & \\
\hline $6-15$ acts & 129 & 72 & 1.2 & $(0.8,2.0)$ & & \\
\hline$\geq 16$ acts & 63 & 42 & & Referent & & \\
\hline \multicolumn{7}{|l|}{ Consistent condom use with "other" partners in past 2 weeks } \\
\hline Yes & 165 & 70 & 2.0 & $(1.2,3.4)$ & 2.1 & $(1.2,3.7)$ \\
\hline No & 68 & 59 & & Referent & Ref & erent \\
\hline Component 1 (Perceived partner support of diaphragm use) & & & 1.2 & $(0.9,1.4)$ & & \\
\hline Component 2 (Attitudes toward study product attributes) & & & 1.2 & $(1.0,1.5)$ & & \\
\hline \multicolumn{7}{|l|}{ Diaphragm + gel use is easier than condom use } \\
\hline Yes & 189 & 79 & 2.5 & $(1.5,4.1)$ & 2.3 & $(1.4,3.8)$ \\
\hline No & 44 & 50 & & Referent & Ref & erent \\
\hline \multicolumn{7}{|l|}{ Important that diaphragm use does not interrupt sex } \\
\hline Yes & 222 & 117 & 2.9 & $(1.3,6.5)$ & 2.2 & $(1.0,5.0)$ \\
\hline No & 11 & 12 & & Referent & & \\
\hline \multicolumn{7}{|l|}{ No need for condoms is benefit of diaphragm + gel use } \\
\hline Yes & 50 & 26 & 1.8 & $(1.0,3.1)$ & 2.3 & $(1.3,4.2)$ \\
\hline No & 183 & 103 & & Referent & Referent & \\
\hline
\end{tabular}

OR = odds ratio; $C I=$ confidence interval

* Analyzed with logistic regression model with generalized estimating equations based on 362 bimonthly study visits from 135 women who reported having sex with "other" partner during at least one bimonthly visit.

${ }^{\dagger}$ Adjusted for all variables in column.

The following variables also were analyzed but were not associated with consistent diaphragm use: ethnicity (Kikuyu versus other), education ( $\leq 9$ USD versus $>9$ USD), important to prevent pregnancy (not at all versus moderately or a lot); worry about pregnancy (not at all versus moderately or a lot); worry about HIV (not at all versus moderately or a lot); new sex partners in past 2 weeks ( 0 versus 1-2 versus $\geq 3$ ); and the remaining factors that did not load in principal component analysis (listed in the footnote for Table 4). 
TABLE 6: Reasons cited for not using diaphragm in previous 2 weeks, overall and by partner type, Nairobi, Kenya, 2004-2005*.

\begin{tabular}{|c|c|c|c|c|c|c|}
\hline \multirow[b]{3}{*}{ Reasons for not using condoms } & & & \multicolumn{4}{|c|}{ Partner type } \\
\hline & \multicolumn{2}{|c|}{ Overall $(N=92)$} & \multicolumn{2}{|c|}{ "Helping" $(N=71)$} & \multicolumn{2}{|c|}{ "Other" $(N=74)$} \\
\hline & No. & $(\%)$ & No. & $(\%)$ & No. & $(\%)$ \\
\hline \multicolumn{7}{|l|}{ Reasons related to partner or coital act } \\
\hline Afraid to ask & 6 & (7) & 4 & (6) & 2 & (3) \\
\hline Did not need protection from STD & 1 & (1) & 0 & $(0)$ & 1 & $(1)$ \\
\hline Trust each other & 44 & $(48)$ & 43 & $(61)$ & 2 & (3) \\
\hline Know each other well enough not to use it & 43 & $(47)$ & 43 & $(61)$ & 4 & $(5)$ \\
\hline Used condoms instead & 69 & $(75)$ & 27 & $(38)$ & 61 & $(82)$ \\
\hline Diaphragm uncomfortable for partner & 8 & $(9)$ & 8 & $(11)$ & 0 & $(0)$ \\
\hline Partner objected to use & 28 & $(30)$ & 20 & $(28)$ & 11 & $(15)$ \\
\hline Unexpected sex/did not have diaphragm & 46 & $(50)$ & 21 & $(30)$ & 39 & $(53)$ \\
\hline Could not use because drunk & 16 & $(17)$ & 9 & $(13)$ & 11 & $(15)$ \\
\hline Forgot to use diaphragm & 28 & $(30)$ & 14 & $(20)$ & 17 & $(23)$ \\
\hline Lost diaphragm & 2 & $(2)$ & 2 & (3) & 2 & (3) \\
\hline \multicolumn{7}{|l|}{ Device-related reasons } \\
\hline Diaphragm uncomfortable for participant & 3 & (3) & 1 & $(1)$ & 2 & $(3)$ \\
\hline Do not like having genitals touched & 3 & (3) & 3 & $(4)$ & 0 & $(0)$ \\
\hline Difficulties inserting or removing & 0 & $(0)$ & 0 & $(0)$ & 0 & $(0)$ \\
\hline Did not need pregnancy protection & 3 & (3) & 2 & (3) & 1 & (1) \\
\hline Do not think effective against STD & 1 & (1) & 1 & (1) & 0 & $(0)$ \\
\hline
\end{tabular}

* Barriers reported during at least one bimonthly follow-up visit. Participant could give multiple reasons. Analysis restricted to the subset of participants reporting inconsistent diaphragm use in the past two weeks with the relevant partner type during at least one bimonthly visit.

partner would support diaphragm use (measured by the principal component analysis) was associated with recent consistent diaphragm use with this partner but not with "other" partners. This difference by partner type could be related to a higher rate of awareness of diaphragm use among "helping" than among "other" partners. Women might have felt a responsibility to inform "helping" partners about their diaphragm use or have judged covert use to be difficult to sustain long term with this partner. They also might have been more concerned about the consequences of a "helping" partner discovering their covert diaphragm use. On the other hand, condom-related factors (reporting consistent condom use and perceiving the lack of need for condoms as a benefit of diaphragm use) were associated with consistent diaphragm use with "other" partners but not with "helping" partners. Overall, our results suggest that future studies of the effect of diaphragm promotion on condom use should account for partner type.

The study's main limitation was its reliance on selfreported data, which has potential for reporting bias. For example, we cannot eliminate the possibility that the apparent increase in diaphragm use over the course of the study resulted from a change in the validity of self-reporting. Women might have overreported consistent diaphragm use more often as the study progressed if they developed closer rapport with the study staff and, thus, had a stronger motivation to "please" staff by reporting adherence to their instructions. Similarly, the association between consistent condom use and consistent diaphragm use with "other" partners could be spurious if the perceived social desirability of using both products caused some women to overreport their use of them. Another limitation is that because the study population consisted of female sex workers in Kibera, Nairobi who did not consistently use condoms and who were willing to try the diaphragm, study findings might not be generalizable to other populations. Finally, just as intention to use study products does not necessarily predict use [27, 28], the level of adherence to consistent diaphragm use (as well as factors related to adherence) among participants in this study might be different in nonstudy settings or be impossible to sustain for periods longer than 6 months.

Although study participants were advised repeatedly of the unknown effectiveness of the diaphragm against STI acquisition and, when used for this purpose, against pregnancy, qualitative data from the exit interview (data not reported here) suggest that women were reluctant to return the diaphragm at the end of the study because they believed that it protected them from acquiring STIs. This finding has been observed elsewhere [14] and highlights the need for better methods for ensuring participant comprehension of key points during research participation. The quantitative measures of participant concern about HIV acquisition (as well as concern about pregnancy and the perceived importance of preventing pregnancy) were not associated with consistent diaphragm use.

Reasons cited for not using the diaphragm with "other" partners included having unexpected sex or not having the diaphragm available. Continuous diaphragm use (except during daily removal for cleaning) could address this barrier. By making its use independent of coitus, continuous use 
of the diaphragm could increase the proportion of sex acts protected by the device and thus improve its effectiveness [29]. However, little research has been conducted on continuous diaphragm use [30], and the safety and effectiveness of such use would need to be proven in future studies before continuous use of diaphragms could be promoted.

Other research has demonstrated that relationship factors influence diaphragm use [31]. To our knowledge, though, this was the first prospective study to evaluate adherence to diaphragm use by partner type. We used only two classifications for partner type; a more refined understanding of partners might have yielded different results. Nevertheless, the differences we found in determinants of consistent diaphragm use during sex with "helping" partners and during sex with "other" partners suggest that future research should also distinguish between different types of partners when evaluating adherence to diaphragm use. Tailoring interventions and counseling messages based on women's types of partners could perhaps help improve efforts to promote consistent diaphragm use.

\section{Acknowledgments}

This study was funded by the U.S. Centers for Disease Control and Prevention (CDC) through an interagency agreement with the U.S. Agency for International Development and CONRAD. The findings and conclusions in this report are those of the authors and do not necessarily represent the views of CDC, nor does mention of trade names, commercial products, or organizations imply endorsement by the U.S. Government.

\section{References}

[1] G. Bolan, A. A. Ehrhardt, and J. N. Wasserheit, "Gender perspectives and STDs," in Sexually Transmitted Diseases, K. K. Holmes, P. G. Sparling, P.-A. Mardh, et al., Eds., pp. 117-127, McGraw-Hill, New York, NY, USA, 3rd edition, 1999.

[2] W. C. Levine, V. Pope, A. Bhoomkar, et al., "Increase in endocervical CD4 lymphocytes among women with nonulcerative sexually transmitted diseases," Journal of Infectious Diseases, vol. 177, no. 1, pp. 167-174, 1998.

[3] B. K. Patterson, A. Landay, J. Andersson, et al., "Repertoire of chemokine receptor expression in the female genital tract: implications for human immunodeficiency virus transmission," American Journal of Pathology, vol. 153, no. 2, pp. 481490, 1998.

[4] L. Zhang, T. He, A. Talal, G. Wang, S. S. Frankel, and D. D. Ho, "In vivo distribution of the human immunodeficiency virus/simian immunodeficiency virus coreceptors: CXCR4, CCR3, and CCR5," Journal of Virology, vol. 72, no. 6, pp. 50355045, 1998.

[5] J. Pudney, Y. M. Wang, C. R. Mackay, and D. Anderson, "Expression of chemokine receptors in human reproductive tissues," in Proceedings of the Annual Meeting of Society for Gynecological Investigation, San Diego, Calif, USA, 1997, abstract no. 49.

[6] L. A. Hussain and T. Lehner, "Comparative investigation of Langerhans' cells and potential receptors for HIV in oral, genitourinary and rectal epithelia," Immunology, vol. 85, no. 3, pp. 475-484, 1995.

[7] J.-A. Røttingen, W. D. Cameron, and G. P. Garnett, "A systematic review of the epidemiologic interactions between classic sexually transmitted diseases and HIV: how much really is known?" Sexually Transmitted Diseases, vol. 28, no. 10, pp. 579-597, 2001.

[8] H. Grosskurth, R. Gray, R. Hayes, D. Mabey, and M. Wawer, "Control of sexually transmitted diseases for HIV-1 prevention: understanding the implications of the Mwanza and Rakai trials," The Lancet, vol. 355, no. 9219, pp. 1981-1987, 2000.

[9] A. M. Minnis and N. S. Padian, "Effectiveness of female controlled barrier methods in preventing sexually transmitted infections and HIV: current evidence and future research directions," Sexually Transmitted Infections, vol. 81, no. 3, pp. 193-200, 2005.

[10] N. S. Padian, A. van der Straten, G. Ramjee, et al., "Diaphragm and lubricant gel for prevention of HIV acquisition in southern African women: a randomised controlled trial," The Lancet, vol. 370, no. 9583, pp. 251-261, 2007.

[11] T. R. Moench, T. Chipato, and N. S. Padian, "Preventing disease by protecting the cervix: the unexplored promise of internal vaginal barrier devices," AIDS, vol. 15, no. 13, pp. 1595-1602, 2001.

[12] A. N. Turner, K. Van Damme, D. J. Jamieson, et al., "Predictors of adherent use of diaphragms and microbicide gel in a fourarm, randomized pilot study among female sex workers in Madagascar," Sexually Transmitted Diseases, vol. 36, no. 4, pp. 249-257, 2009.

[13] F. M. Behets, A. N. Turner, K. Van Damme, et al., "Vaginal microbicide and diaphragm use for sexually transmitted infection prevention: a randomized acceptability and feasibility study among high-risk women in Madagascar," Sexually Transmitted Diseases, vol. 35, no. 9, pp. 818-826, 2008.

[14] F. M. Behets, K. Van Damme, A. N. Turner, et al., "Evidencebased planning of a randomized controlled trial on diaphragm use for prevention of sexually transmitted infections," Sexually Transmitted Diseases, vol. 35, no. 3, pp. 238-242, 2008.

[15] S. Luchters, M. F. Chersich, I. Jao, et al., "Acceptability of the diaphragm in Mombasa Kenya: a 6-month prospective study," European Journal of Contraception \& Reproductive Health Care, vol. 12, no. 4, pp. 345-353, 2007.

[16] A. Sharma, E. Bukusi, S. Posner, D. Feldman, E. Ngugi, and C. R. Cohen, "Sex preparation and diaphragm acceptability in sex work in Nairobi, Kenya," Sexual Health, vol. 3, no. 4, pp. 261-268, 2006.

[17] F. Behets, A. N. Turner, K. Van Damme, et al., "Acceptability and feasibility of continuous diaphragm use among sex workers in Madagascar," Sexually Transmitted Infections, vol. 81, no. 6, pp. 472-476, 2005.

[18] J. Buck, M.-S. Kang, A. van der Straten, G. KhumaloSakutukwa, S. Posner, and N. Padian, "Barrier method preferences and perceptions among Zimbabwean women and their partners," AIDS and Behavior, vol. 9, no. 4, pp. 415-422, 2005.

[19] A. van der Straten, M. S. Kang, S. F. Posner, M. Kamba, T. Chipato, and N. S. Padian, "Predictors of diaphragm use as a potential sexually transmitted disease/HIV prevention method in Zimbabwe," Sexually Transmitted Diseases, vol. 32, no. 1, pp. 64-71, 2005.

[20] S. T. Bird, S. M. Harvey, J. E. Maher, and L. J. Beckman, "Acceptability of an existing, female-controlled contraceptive method that could potentially protect against HIV: a 
comparison of diaphragm users and other method users," Women's Health Issues, vol. 14, no. 3, pp. 85-93, 2004.

[21] A. van der Straten, S. Shiboski, E. T. Montgomery, et al., "Patterns and predictors of adherence to diaphragm use in a phase III trial in sub-Saharan Africa: a trajectory analysis," Journal of Acquired Immune Deficiency Syndromes, vol. 50, no. 4, pp. 419-426, 2009.

[22] J. Okal, J. Stadler, W. Ombidi, et al., "Secrecy, disclosure and accidental discovery: perspectives of diaphragm users in Mombasa, Kenya," Culture, Health and Sexuality, vol. 10, no. 1, pp. 13-26, 2008.

[23] M.-S. Kang, J. Buck, N. Padian, S. F. Posner, G. KhumaloSakutukwa, and A. van der Straten, "The importance of discreet use of the diaphragm to Zimbabwean women and their partners," AIDS and Behavior, vol. 11, no. 3, pp. 443-451, 2007.

[24] R. Kaul, J. Kimani, N. J. Nagelkerke, et al., "Monthly antibiotic chemoprophylaxis and incidence of sexually transmitted infections and HIV-1 infection in Kenyan sex workers: a randomized controlled trial," Journal of the American Medical Association, vol. 291, no. 21, pp. 2555-2562, 2004.

[25] I. T. Joliffe and B. J. Morgan, "Principal component analysis and exploratory factor analysis," Statistical Methods in Medical Research, vol. 1, no. 1, pp. 69-95, 1992.

[26] S. F. Posner, L. Pulley, L. Artz, and M. Macaluso, "Use of psychometric techniques in the analysis of epidemiologic data," Annals of Epidemiology, vol. 13, no. 5, pp. 344-350, 2003.

[27] A. M. Minnis, S. C. Shiboski, and N. S. Padian, "Barrier contraceptive method acceptability and choice are not reliable indicators of use," Sexually Transmitted Diseases, vol. 30, no. 7, pp. 556-561, 2003.

[28] L. J. Severy, E. Tolley, C. Woodsong, and G. Guest, "A framework for examining the sustained acceptability of microbicides," AIDS and Behavior, vol. 9, no. 1, pp. 121-131, 2005.

[29] A. Penman-Aguilar, T. Swezey, A. Bell, et al., "The importance of continuous use for achieving consistent protection: a mixed-method analysis of the diaphragm used with a candidate microbicide for the prevention of STI," in Proceedings of the International Society for Sexually Transmitted Diseases Research, Seattle, Wash, USA, 2007.

[30] A. E. Ferreira, M. J. Araújo, C. H. Regina, S. G. Diniz, and A. Faúndes, "Effectiveness of the diaphragm, used continously, without spermicide," Contraception, vol. 48, no. 1, pp. 29-35, 1993.

[31] L. J. Beckman, S. M. Harvey, S. Thorburn, J. E. Maher, and K. L. Burns, "Women's acceptance of the diaphragm: the role of relationship factors," Journal of Sex Research, vol. 43, no. 4, pp. 297-306, 2006. 


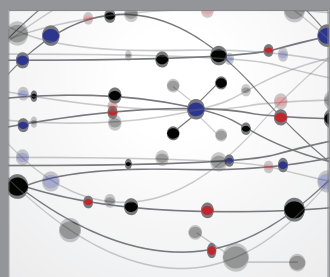

The Scientific World Journal
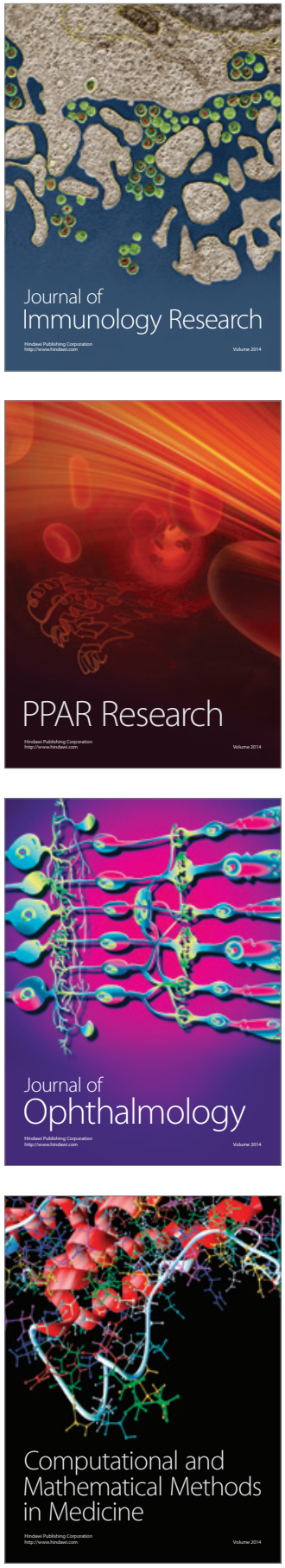

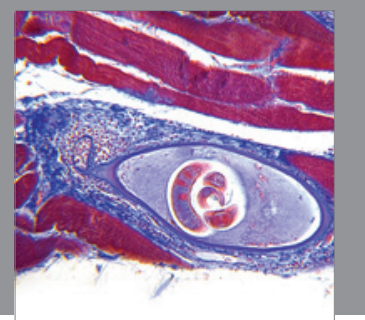

Gastroenterology

Research and Practice
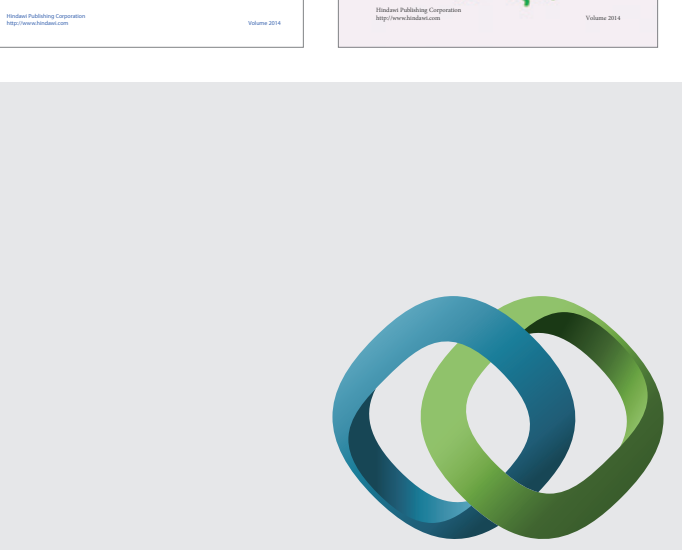

\section{Hindawi}

Submit your manuscripts at

http://www.hindawi.com
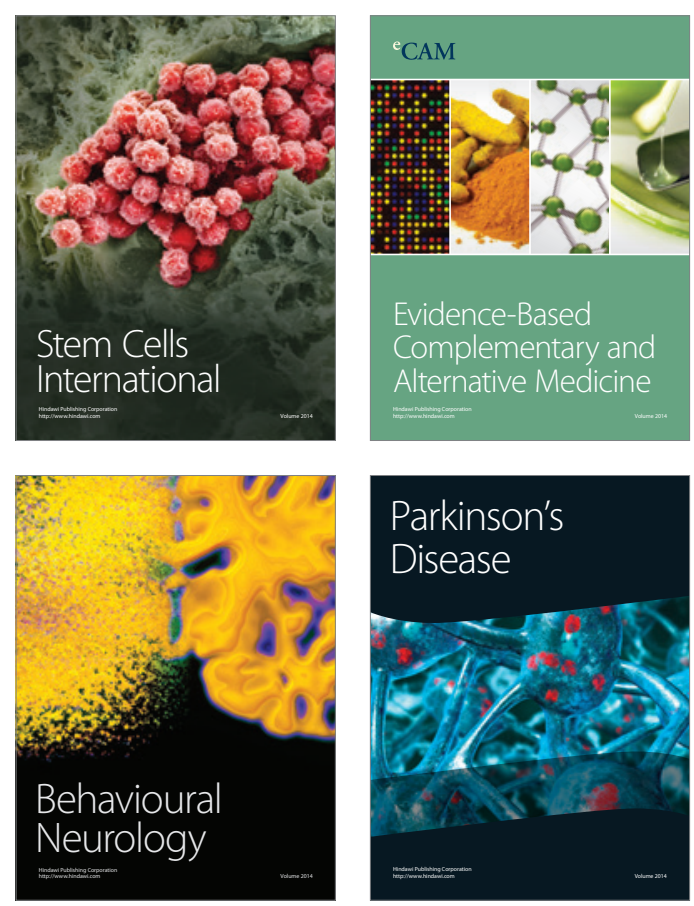

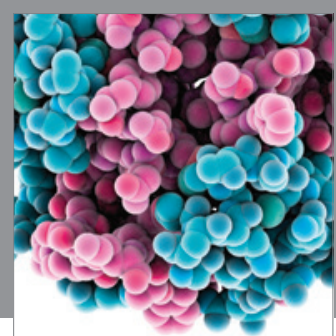

Journal of
Diabetes Research

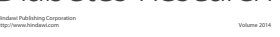

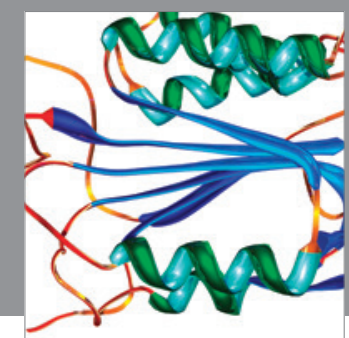

Disease Markers
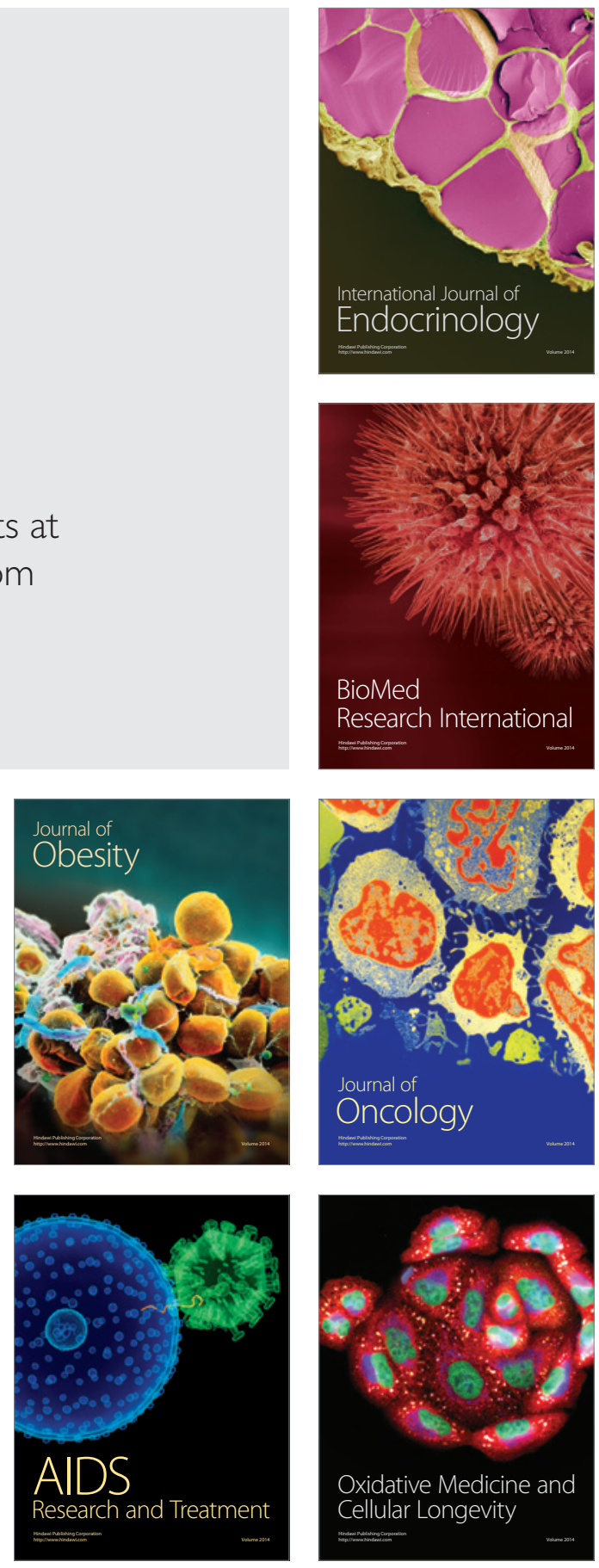